and the author of the nolice referred to is therefore invited to furnish a parallel calculation, based upon the theories which have hitherto received general support. This invitation the writer must decline, simply because two far abler hands than his have already investigated this problem on the lines which he would have pursued; and he could add nothing to the authority that accompanies the utterances of Dr. J. R. Hind, the Superintendent of the English "Nautical Almanac," an Prof. Simon Newcomb, the Superintendent of the American.

The following is Mr. Page's communication :-

"Herodotus speaks of the eclipse of Thales as follows :- 'A war commenced between the I,ydians and the Medes, ... . which continued five years; and it is remarkable that one of their engagements took place in the night. In the sixth year, when they were carrying on the war with nearly equal success, on the occasion of an engagement, it happened that in the heat of hattle day was suddenly turned into night' (Herodotus, b. i., s. 74).

"This battle was fought on the morning of the (Julian) July 8 , or 9 days after the solstice; consequently in the time of longest dlays and hottest weather. It would seem from the above account that it commenced in the night, and iwas not ended until the time of the eclipse, or 5.24 a.m.; when the armies ceased fighting on account of their fears.

'From Ptolemy's canon we learn that Cyaxares, King of Media, began to reign B.C. 634 , and reigned 40 years, during 28 of which the Scythians ruled over Asia. In B. C. 606 the Scythian power was broken, and the Medes and Babylonians conquered Assyria. Soon afterwards (i.e. in B.C. 603) that war broke out between Lydia and Media which was terminated by mutual fears of this eclipse. As the King of Media reigned 40 years from B.C. 634 , he must have died B.C. 594, which is the latest date that can be fixed for the eclipse ; and as he was 28 years subject to the Scythians, he must have reigned 12 years after the defeat of the Scythians in B.C. 606 ; and as his war with the Lydians could not have taken place for several years after this, and as the eclipse was in the sixth year of the war, the date of the eclipse cannot possibly be placed earlier than B.C. 600 : consequently we are compelled to look for it some time between B.C. 600 and B.C. $594, "$

Appended to this communication is a calculation by $\mathrm{Mr}$. Page of the time of new moon in B.C. 597. This calculation is founded upon Ferguson's tables, to which some corrections bave been applied by the computer. The calculation cannot be given here in detail; but the result to which Mr. Page is led is July $8,5 \mathrm{~h} .24 \mathrm{~m}$. IIs., as that at which the so-called eclipse of Thales occurred. This date differs some twelve years from that which has been assigned by the two authorities just mentioned, viz. B.C. 585-a date, too, which accords with that mentioned by Pliny, reckoned by Olympiads. But those who find Mr. Page's arguments sufficient will agree with him; my regret is rather that he has chosen to build his theory on absolute tables, and to ignore all that the ablest astronomers and mathematicians have recently been able to accomplish in this direction. William E. Plummer.

\section{The Rotation of Mercury.}

In your issue for January $\mathbf{r} 6$ (xli. p. 257), Schiaparelli's observa4 ions on the planet Mercury are stated to lead that astronomer to the conclusion that "Mercury revolves around the sun in the same manner that the moon revolves round the earth, always presenting to it the same hemisphere."

Permit me to recall the fact that, as a matter of deductive reasoning, I recorded this opinion in 1883 : "The powerful tidal action experienced by Mercury has greatly retarded its primitive axial motion, and increased its distance from the sun. No surprise would be occasioned by the proof that the planet has already attained to synchronistic motions" ("World-Life," p. 425). This opinion was accompanied by calculations of the solar tidal efficiency on Mercury.

Alexander Winchell.

\section{Wet and Dry Bulb Thermometers.}

IT may, perhaps, interest you to know that on Friday last the difference between the wet and dry bulb thermometers, on board this ship in Grimsby roads, amounted to $12 \frac{1}{2}^{\circ}$; the dry bulb showing $66^{\circ}$, and the wet bulb $53^{\circ} .5$. Wind west ; force,
7 to 8 by Beaufort's scale. This is the greatest difference I have recorded in this country for ten years.

H.M.S. Triton, Grimsby, August 17.

\section{Experiment in Subjective Colours.}

THE following experiment does not seem to be widely known it is not easy to make a clear explanation of the lenses.

Take a number of the Graphic and a piece of thin paper, which, if put upon the ordinary print, allows it to be seen througb, as black. Now put the paper over some of the large black letters on the apple-green outer cover: seen through the paper, they appear as bright red.

Winchester College, August I8.

\section{THE SCIENCE AND ART MUSEUM, DUBLIN AND THE NATIONAL LIBRARY OF IREL AND.}

T $\mathrm{N}$ the year 1877 the Natural History Museum and the Library of the Royal Dublin Society, which, though mainly supported for many years by Parliamentary grants, had been directly managed by the Society, were, by Act of Parliament, transferred to the Science and Art Department, a large sum of money having been at the same time paid by Government to the Society for ceding its rights and property.

Soon afterwards steps were taken by the Science and Art Department for providing suitable accommodation for an art and industrial addition to the Museum. Into a consideration of the various causes which delayed the carrying out of this project we need not enter here; they will be found described in the Reports of the Science and Art Department.

At length, in 1884 , a final competition between rival architects' designs for the new buildings was arrived at, and those by Messrs. Deane and Son, of Dublin, were chosen by the representative committee, which was specially appointed for the purpose of selection.

The sites for these buildings, which were adopted after much discussion, are at right angles to Leinster Houseon its Kildare Street or western side. The facades of both buildings, which face one another, are about 200 feet long, and are similar, consisting of two rotundas with colonnades, and pavilions at the sides: In the centre of the Museum building is a large court about 125 feet by 75 feet. Opening from it there are in all 24 galleries or rooms, which are devoted to exhibiting purposes.

The foundations were laid by His Royal Highness the Prince of Wales on April Io, 1885, the ceremony connected therewith being the most important presided over by His Royal Highness during his last visit to Ireland.

The tender for the erection of the buildings by Messrs. Beckett Brothers, of Dublin, was accepted on November 3, and by the 17 th operations had commenced. In four years, or by November I 889 , the Museum building was completed, and was handed over to the Science and Art Department, and the transfer to the new galleries of the collections which had accumulated in the temporary premises during twelve years was at once proceeded with.

It was not until June of the present year that the sister building, for the reception of the National Library of Ireland, was completed. During the month of July the transfer of the books, consisting of about I00,000 volumes, from the old Library in Leinster House, has been satisfactorily accomplished.

Both institutions are about to be opened on the 29th of the present month by His Excellency the Lord-Lieutenant, after which they will continue to remain open and free to the public.

It may be of interest to add some details as to the principal contents and system of arrangement in the two institutions respectively. In order to describe the Museum

NO. IO86, VOL. 42] 